\title{
Migrant Remittances and Agricultural Production Under Climate Change: Evidence From Rural Households in Nigeria
}

\author{
Nsikak-Abasi A. Etim ${ }^{a^{*}}$, Dorothy Thompson ${ }^{b}$, Ubong A. Asa ${ }^{a}$ \\ ${ }^{a}$ Department of Agricultural Economics and Extension, University of Uyo, P. M. B 1017, Uyo, Akwa Ibom State, Nigeria. \\ ${ }^{b}$ Department of Home Economics, University of Uyo, P. M. B 1017, Uyo, Akwa Ibom State, Nigeria.
}

Received: 05 September 2020 / Revised: 17 October 2020 / Accepted: 06 December 2020

\begin{abstract}
Majority of Nigeria's rural poor especially smallholder farmers who rely on agricultural production for their subsistence face considerable difficulties in increasing productivity due to the adverse impact of changes in climate. But migrant remittance has become an important part of the strategy for rural households to cope with negative environmental consequences through reduction in vulnerability to climate variability, improvement in livelihood and expansion in production. An empirical study to measure the impact of migrant remittances on small holder agricultural production was conducted. Through the multistage sampling technique, 120 smallholder farmers were selected and data were collected using questionnaire. Multiple regression analysis based on CobbDouglas production function was used to determine the impact of migrant remittance on agricultural production. Result of the analysis revealed that the most critical factors which positively and significantly $(p<0.05)$ influenced the output of remittance receiving households were education, experience, farm size and labour. Findings also showed that the same covariates also influence output of non-remittance receiving households. Policies to increase the inflow of remittances to poorer households engaging in agricultural production would be a rational decision.
\end{abstract}

Keywords: Migration, remittance, agriculture, output, climate.

(c) Euraass 2020. All rights reserved.

\section{Introduction}

Migrant remittances are portion of workers' earning or available income sent to their families back home (Asogwa, 2013; Osondu et al., 2014; Davis \& Lopez- Carr, 2014; Redehegn et al., 2019) and they are essential in adaptation to climate change (Musah-Surugu,2018; Oronzo and Jewers, 2019). Remittances have been useful in stimulating local economies, reducing poverty and improving agricultural production (Nwaru et al., 2011). Although, poor rural households are struggling with the challenge of climate impacts Musah-Surugu et al. (2018) and the agricultural sector is constrained by changes in climate (Etim and Etim, 2020) agricultural production and food security have been negatively impacted by these changes (Muller et al., 2011; Ndamani and Watanabe, 2017). Furthermore, the adverse impacts of weather and climate vagaries coupled with the rising cost of agricultural inputs, low farm income have greatly diminished the ability of rural farm families to expand production. Consequent upon this,

*Corresponding author: Email: etimbobo@gmail.com, (Nsikak-Abasi A. Etim).

Available online: 30 December 2020

DOI: https://doi.org/10.34154/2020-ASSJ-0202-13-23/euraass

Journal reference: Arts and Social Sciences, 2020, 1(1): 13-23.

ISSN-E: 2743-4664

(c) European Academy of Applied and Social Sciences. Euraass - 2020. All rights reserved. 
research has centered more and primarily on climate change. Studies by Chukwuome et al. (2007); Oseni \& Winter, (2009) and Babatunde and Martinelti (2010) have reported the impact of remittance on development, welfare, food security, poverty and income inequality. There has been limited studies regarding the impact of remittance on agricultural production under changes in climate and this has resulted in a huge lacuna. However, to formulate policies that will encourage the inflow of remittances which will stimulate agricultural production in a tropical climate and enable farmers to cope with the adverse effect of changes in climate, a study of migrant remittances and agricultural production deserves attention. This study was therefore conducted to estimate the impact of remittances on agricultural production.

\section{Methodology}

\subsection{Study Area}

This study was carried out in Akwa lbom State, Nigeria. The state is located within the humid tropical rainforest region and lies between latitude $4^{\circ} 33^{\prime}$ and $5^{\circ} 53^{\prime}$ North and longitude $7^{\circ} 25^{\prime}$ and $8^{\circ} 25^{\prime}$ East. According to the population estimates by National Population Commission (2006), it has a population of 3,920,208 million people comprising 2,044,510 males and 1,875,698 females. It covers a total land area of 8,412 square kilometers is bordered by Abia state on the North, Cross River State on the East, Rivers and Abia States on the West and on the south by Atlantic Ocean. There are six (6) Agricultural Development Project (ADP) zones viz; Uyo, Eket, Oron, Abak, Etinan and Ikot Ekpene and 2 distinct seasons viz; rainy season and short dry season. The mean annual temperature in the state is between $26^{\circ} \mathrm{C}$ and $29^{\circ} \mathrm{C}$ while the average sunshine accumulates to 1,450 hours per annum. The annual precipitation ranges between $2000 \mathrm{~mm}$ to $3000 \mathrm{~mm}$ per annum. The predominant occupation of most inhabitants is farming.

\subsection{Sampling and Data Collection Technique}

Multistage sampling technique was used in selecting the representative sample. The first stage involved the random selection of 3 out of the 6 Agricultural Development Project (ADP) zones. The second stage involved the random selection of 2 blocks from each ADP zone to make 6. Thirdly, 2 communities were randomly from each of the blocks to make 12 . Finally 5 remittance and non-remittance receiving households each were randomly selected from each of the communities to make 120 primary date were obtained from farmers using the cost route method. Because most rural farmers do not keep farm records as they rely more on mental recording, data were collected from farmers on a weekly basis. Data were collected with the aid of questionnaire.

Data were analyzed using multiple regression analysis based on Cobb-Douglas production chow and z-test.

The $Z$ test statistics is given by $Z_{\text {cal }}=\left(\bar{x}_{1}-\bar{x}_{2}\right) / S \bar{x}_{1}-\bar{x}_{2}$

$$
S \bar{x}_{1}-\bar{x}_{2}=\quad \sqrt{\left.S^{2} x_{1} / n_{1}\right)+\left(S^{2} x_{2} / n^{2}\right)}
$$

where in equation (1) and (2), $\bar{x}_{1}$ and $\bar{x}_{2}$ are the mean values of the major socioeconomic variables of the migrant remittance receiving and non-receiving households respectively; $S^{2} \bar{x}_{1}$ and $S^{2} \bar{x}^{2}$ are variances of the major socioeconomic variables of the remittance receiving and non-receiving households respectively.; $n_{1}$ and $n_{2}$ are the number of households in each group respectively; $\mathrm{Sx}_{1}-\mathrm{x}_{2}$ are sample standard error of the means to estimate the impact of migrant remittances on farmers output, a Cobb-Douglas production function was specified for the two groups of households separately. The data were pooled and analyzed in (see equation 3). The pooled data with dummy (equation 4) representing household type was also analysed. The model is specified implicitly are

$Y=f\left(X_{1 i} ; X_{2 i}, X_{3 i}, X_{4 i}, X_{5 i}, X_{6 i}, X_{7 i} X_{8 i}\right)$

$$
(i=1,2)
$$

$Y=f\left(X_{1}, X_{2}, X_{3}, X_{4}, X_{5} X_{6}, X_{7}, X_{8}, D\right)$

where in equations (3) and (4) is the grain equivalent output of crops in $\mathrm{kg}$ (Olayemi, 1986); $X_{1}=$ Age in years; $X_{2}=S e x(D=1$ if male, 0 if female); $X_{3}=$ Educational level in years; $X_{4}=$ Experience in years, $X_{5}=$ Farm size in hectares; $X_{6}$ is labour measured in man days; $X_{7}=$ Agro chemicals in naira; $X_{8}=$ Fertilizer in kilogram; $e=$ error term and 1 the farm household group. 


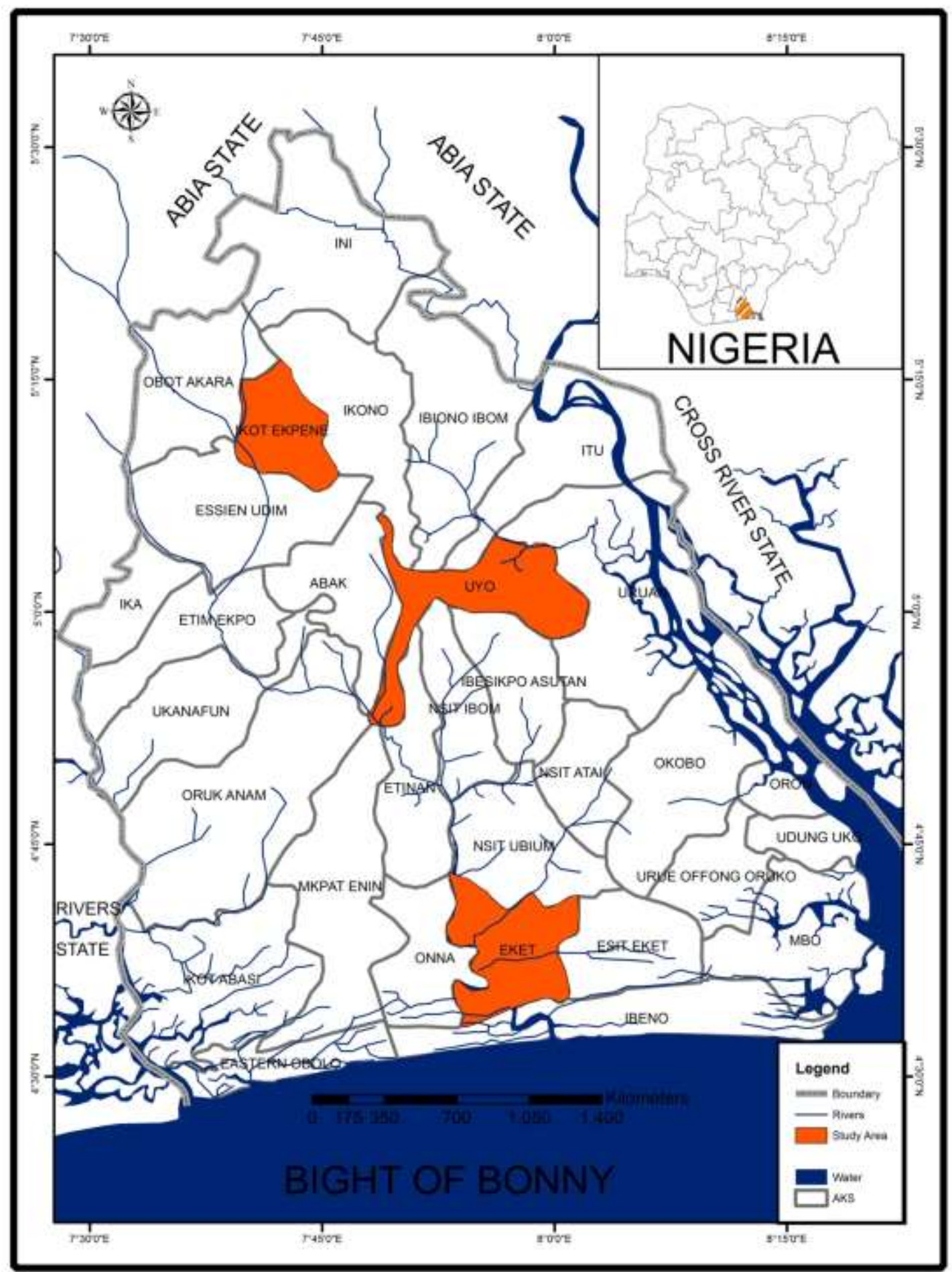

Figure 1: Map of Akwa lbom State Showing the Study Area. 
Chow statistics was used to test if there was significant difference in production function of the two groups of households and is computed following and Onyenweaku (1997) Olomola (1998). The chow test for production change (structural shift in production function is given by

$$
\mathrm{F}^{*}=\frac{\left[\Sigma \mathrm{e}^{2}{ }_{3}-\left(\Sigma \mathrm{e}^{2}{ }_{1}+\Sigma \mathrm{e}^{2}{ }_{2}\right] /\left[\mathrm{k}_{3}-\mathrm{k}_{1}-\mathrm{k}_{2}\right]\right.}{\left(\Sigma \mathrm{e}_{1}{ }_{1}+\Sigma \mathrm{e}_{2}{ }_{2}\right) /\left(\mathrm{k}_{1}+\mathrm{k}_{2}\right)}
$$

where in equation (5), $\Sigma \mathrm{e}_{2}^{2}$ and $\mathrm{k}_{3}$ are the error sum of square and degree of freedom respectively of the sample of migrant remittance receiving households; and $\Sigma \mathrm{e}^{2}$ and $\mathrm{k}_{2}$ are the error sum of square and degree of freedom respectively of the sample of non-remittance receiving households.

To test for homogeneity of slope, chow $\mathrm{F}$ - statistics was calculated as follows:

$$
\mathrm{F}^{*}=\frac{\left[\Sigma \mathrm{e}^{2}{ }_{4}-\left(\Sigma \mathrm{e}^{2}{ }_{1}+\Sigma \mathrm{e}^{2}{ }_{2}\right] /\left[\mathrm{K}_{4}-\mathrm{K}_{1}-\mathrm{K}_{2}\right]\right.}{\left.\left(\Sigma \mathrm{e}^{2}{ }_{1}+\Sigma \mathrm{e}^{2}{ }_{4}\right) / \mathrm{k}_{1}+\mathrm{K}_{2}\right)}
$$

where in equation (6), $\Sigma \mathrm{e}^{2}{ }_{4}$ and $\mathrm{K}_{4}=$ the error sum of square and degree of freedom respectively for the pooled data with a dummy variable with a value of unity for remittance receiving households and zero for non-remittance receiving households, while other variables were as previously defined.

To test for differences in intercept, chow F-statistics was calculated as follows:

$$
F^{*}=\frac{\left[\Sigma e^{2}{ }_{3}-\left(\Sigma e^{2}{ }_{1}+\Sigma e^{2}{ }_{4}\right] /\left[K_{3}-K_{4}\right]\right.}{\left.\left(\Sigma e^{2}{ }_{4}\right) / k_{4}\right)}
$$

where all variables in equation (7) were as previously defined.

The theoretical value of $F$ is the value that defines the critical region of the test at the chosen level of confidence (Koutsoyiannis, 2001). If the calculated $F$ exceeds the tabulated $F$ value, then the intercepts are assumed to be different between the households. This test is conditional on a common slope, so the test for differences in slopes is performed first before testing for differences in intercept (Onyenweaku, 1997).

\section{Result and Discussion}

\subsection{Socioeconomic Attributes of Smallholder Farmers}

Result of the socio economic characteristics of smallholder farmers revealed that majority $(66.67 \%)$ of the sampled farmers were males. Findings also showed that most (75\%) of the farmers were within the economically active age of 20 to 60 years. About $73.33 \%$ of the farmers were married. Findings also revealed that more than 90 percent of the farmers had formal education. Result showed that most farms were in small plots and majority of the farmers had more than 20 years' experience in farming. Figure 1 reveals that most of $(66.67 \%)$ of the farmers were men whereas only 33.33 percent were female. About $26.67 \%$ of the farmers were single as shown in figure 3, whereas $73.33 \%$ were married. Figure 2 shows the most of the $(75 \%)$ farmers were within economically active and productive age. The educational background of the farmers is shown in figure 4 .

The result revealed that most farmers had high literacy level (92\%) had attained primary and post primary education. This is indicative of the fact that rural farmers could make informed decisions on how to channel the remittances into meaningful agricultural production. The experience in farming is shown in figure 5. Majority of the farmer (52\%) had more than 20 years' experience in farming whereas only (15\%) had 1-10 years' experience in farming. The result implies that most farmers had long years of experience about the contribution of remittances to agricultural production. 

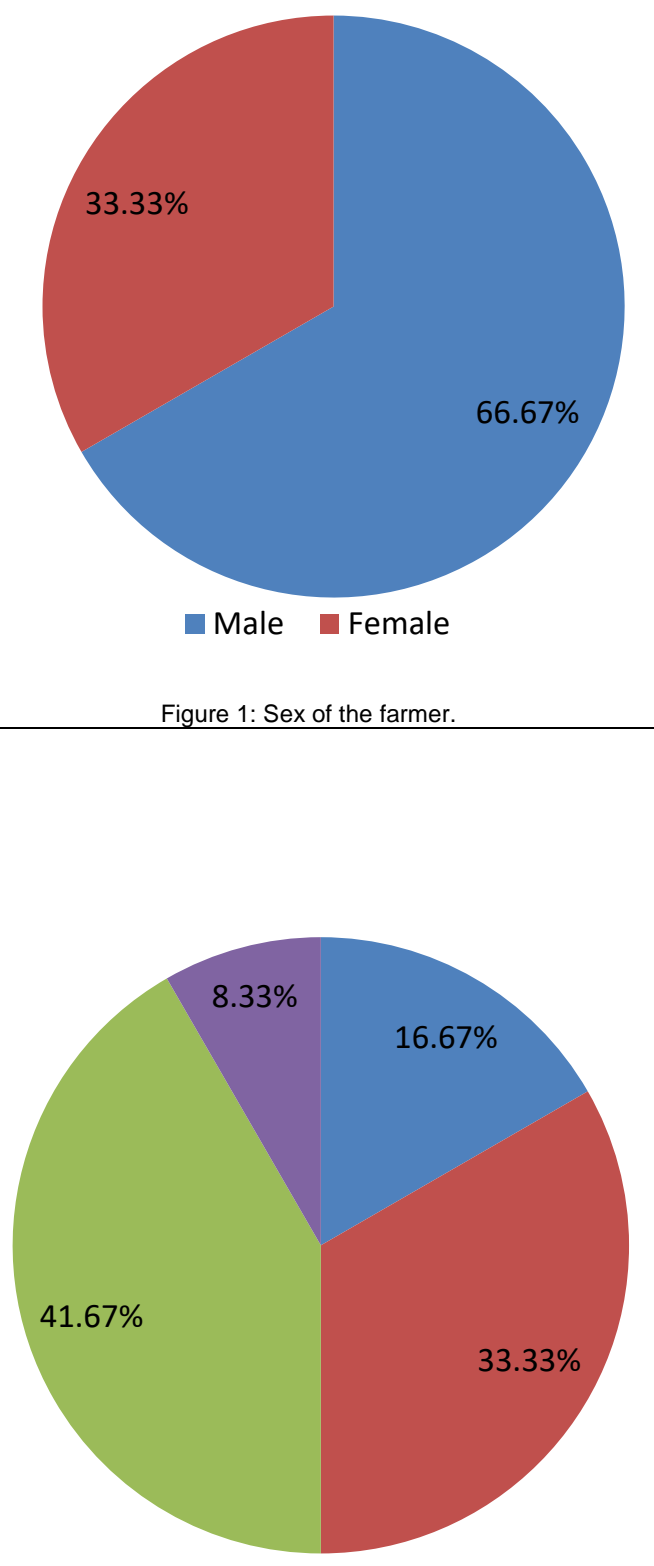

-1--20 $\square$ 21-40 $\square 1-60 \square>60$ 


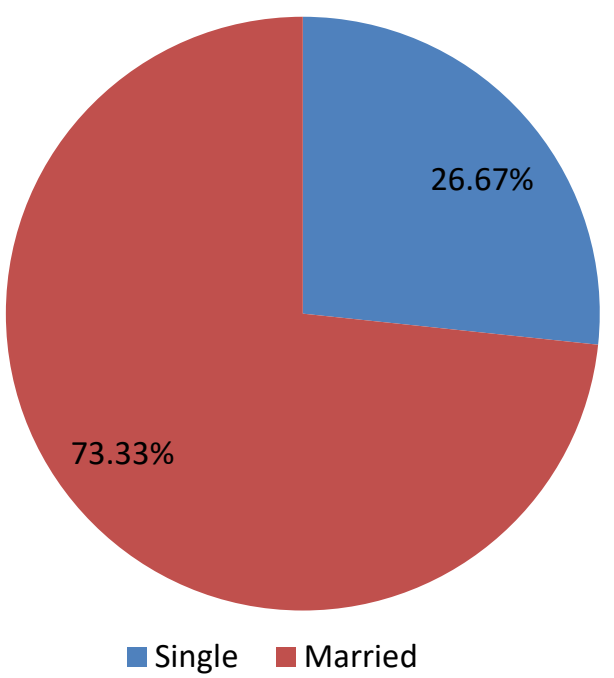

Figure 3: Marital Status of Farmers.

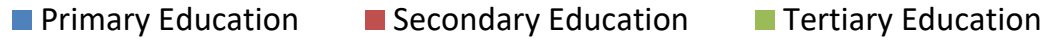

Figure 4: Educational Level of Farmers. 


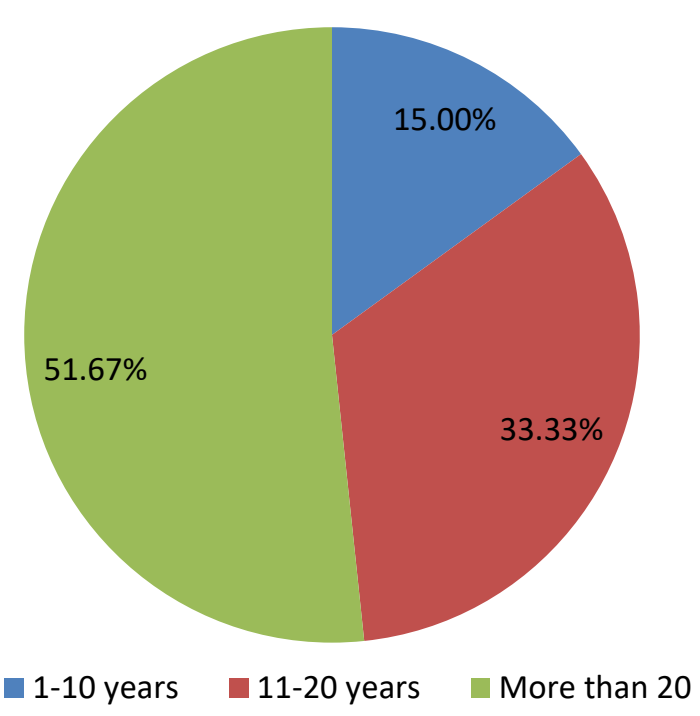

Figure 5: Farming Experience of farmers.

The farm size of the farmers is shown in figure 6 . Most of the farmers (73.33 percent) cropped farmlands less than 1 hectare whereas $26.67 \%$ percent cropped farms between $1-2$ hectares. This result suggests that majority of the farmers cultivated waterleaf mainly for subsistence.

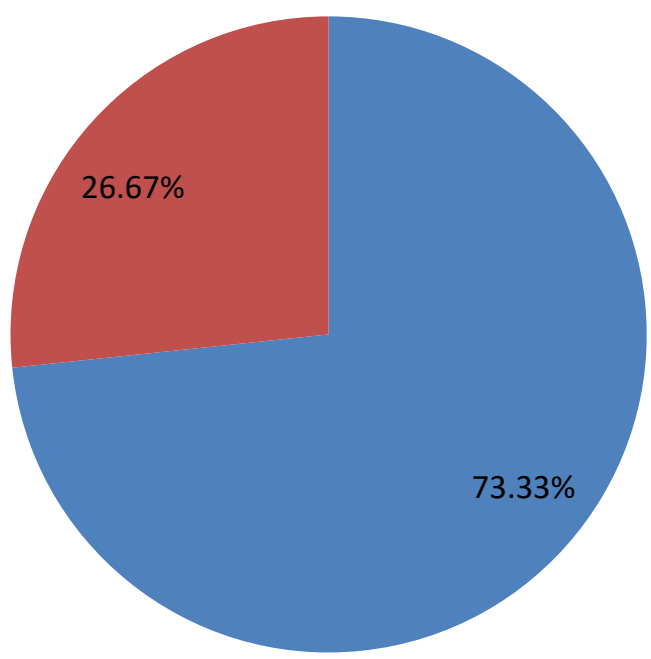

$\square<1 \quad 1--2$

Figure 6: Farm Size of farmers.

3.2 Summary Statistics of the Socio-economic and Farm Specific Characteristics of remittance receiving and nonremittance receiving households

Table 1 shows the mean, minimum, maximum value and standard deviations of some explanatory variables and output of the remittance and output of the remittance and receiving and non-receiving households. 
Table 1: Summary Statistics of Socioeconomic Variables and Output.

\begin{tabular}{|c|c|c|c|c|}
\hline Variable/Household Type & Minimum Value & $\begin{array}{c}\text { Maximum } \\
\text { Value }\end{array}$ & Mean & Standard Deviation \\
\hline Age 1 & 29 & 70 & 50.6 & 12.43 \\
\hline Age 2 & 25 & 71 & 44.9 & 12.98 \\
\hline Farm size 1 & 0.5 & 5.0 & 1.80 & 1.38 \\
\hline Farm size 2 & 0.5 & 4.0 & 1.0 & 0.72 \\
\hline Educational level 1 & 1.0 & 14.0 & 8.93 & 5.51 \\
\hline Educational level 2 & 1.0 & 14.0 & 8.63 & 5.60 \\
\hline Farming experience 1 & 5.0 & 43.0 & 23.53 & 9.86 \\
\hline Farming experience 2 & 8.0 & 48.0 & 24.10 & 12.37 \\
\hline Labour 1 & 21 & 81 & 31.02 & 13.41 \\
\hline Labour 2 & 17 & 72 & 28.01 & 5.39 \\
\hline Fertilizer 1 & 20 & 250 & 74.17 & 58.42 \\
\hline Fertilizer 2 & 20 & 180 & 42.33 & 29.50 \\
\hline Household Income 1 & 5000 & 70,000 & 59,968 & 13,844 \\
\hline Household Income 2 & 19,800 & 42,000 & 24,456 & 29,089 \\
\hline Household size 1 & 3 & 12 & 6.43 & 3.15 \\
\hline Household size 2 & 2 & 10 & 4.87 & 2.90 \\
\hline Output 1 & 1,000 & 45,905 & 14,176 & 8,805 \\
\hline Output 2 & 2200 & 11,150 & 6,420 & 2,495 \\
\hline
\end{tabular}

Here household type 1 and 2 represent remittance receiving and non-remittance receiving households, respectively.

\subsection{Production Function Estimates}

The estimated production functions for the two groups of households, the pooled data and the pooled data with dummy is presented in Table 2. The fact that all the F-ratios were statistically significant at 1 and 5 percent levels is indicative of goodness of fit of the model. The coefficients of multiple determinations $R^{2}$ were $0.7051,0.6431,0.7290$ and 0.6911 for remittance receiving, households, non-receiving households, the pooled data and the pooled data with dummy indicating household type respectively. The result implies that 70.51 percent, 64.31 percent, 72.90 percent and 69.11 percent variation in output of the remittance receiving households, the non-receiving households, the pooled data and the pooled data with dummy indicating household type respectively were accounted for by variables included in the models. The most critical factors influencing the output of the remittance and nonremittance receiving households were education, experience, farm size and labour.

Education was significant $(p<0.05)$ for remittance and $(p<0.01)$ non-remittance receiving households respectively and positively related to output. This implies that as households acquire more education; their agricultural output is likely to increase. This is because knowledge acquired through formal educational system affords them the opportunity to make inform decisions on proper allocation of productive resources in order to maximize output. Nwaru et al. (2011) reported that the education of household members affords them the opportunity to use resources more efficiently and increase farm output and welfare. This result conforms 
to a priori expectations and is synonymous with earlier empirical findings by Huy and Nonneman (2015).

The variable experience was significant $(p<0.05)$ for both household types and positively related to output. This result implies that both households' types were engaged in agriculture over a long time and had acquired more experience about the farming practice that resulted in increased outputs. Earlier empirical finding by lheke (2014) corroborate with this result.

Farm size for both remittance receiving and non-remittance receiving households were significant $(p<0.01$ and $p<0.05)$ and positively related to output. This result implies that increasing the size of cultivable land would increase output level. Similar finding was obtained by Iheke and Aniocha (2017). The variable labour was positively related to output and significant $(p<0.05)$. This conforms to a prior expectation and implies that increasing farm labour would result in higher output and income. This result is contrary to earlier empirical findings by Iheke (2014).

The dummy representing household type was positively related to output and significant $(p<0.05)$. This result implies that remittance receiving households obtained higher output than the non-receiving households. This may be attributable to the fact that portions of migrant earnings are sent home enable families to acquire additional resources, expand production and improve their wellbeing. Gupta et al., (2009) reported that inflows of remittances increase the economic growth and reduce the poverty by stimulating the income of the recipient country, reducing credit constraints, accelerating investment, enhancing human development through financing better education and health. This result is consistent with earlier empirical findings by Etim and Edet (2014) who reported that remittances may be a vehicle to reduce poverty levels by spending on improved nutrition, financial children's schooling or basic health care, or constructing their own home.

Table 2: Estimates of Cobb-Douglas Production functions

\begin{tabular}{|c|c|c|c|c|c|c|c|c|}
\hline \multirow{2}{*}{$\begin{array}{l}\text { Variables } \\
\text { Constant }\end{array}$} & \multicolumn{2}{|c|}{$\begin{array}{c}\text { Remittance Receiving } \\
\text { Households Coefficient } \\
\text { ratio }\end{array}$} & \multicolumn{2}{|c|}{$\begin{array}{c}\text { Non-Remittance Receiving } \\
\text { Households Coefficient } \\
\text { ratio }\end{array}$} & \multicolumn{2}{|c|}{$\begin{array}{c}\text { Pooled } \\
\text { Coefficient Ratio }\end{array}$} & \multicolumn{2}{|c|}{$\begin{array}{c}\text { Pooled with dummy } \\
\text { Coefficient ratio }\end{array}$} \\
\hline & 2.312 & $6.54^{* \star *}$ & 3.001 & $4.33^{\star *}$ & 2.082 & 1.40 & 1.832 & 2.31 \\
\hline Age & 3.003 & 1.07 & 1.631 & 1.02 & 0.812 & 0.45 & 0.018 & 1.42 \\
\hline Sex & 1.010 & 1.44 & 0.002 & 0.24 & 0.791 & 0.96 & 0.081 & 1.17 \\
\hline Education & 1.602 & $2.47^{* *}$ & 2.180 & $4.91^{\star * *}$ & 0.051 & $2.18^{* *}$ & 0.012 & 0.91 \\
\hline Experience & 0.251 & $2.03^{\star \star}$ & 0.013 & 1.94 & 0.095 & 1.02 & 0.066 & 0.99 \\
\hline Farm size & 1.337 & $2.56^{\star *}$ & 0.125 & $2.71^{\star *}$ & 0.813 & $1.91^{*}$ & 1.085 & 0.81 \\
\hline Labour & 0.011 & $2.23^{\star *}$ & 0.001 & $3.33^{\star *}$ & 0.361 & $2.55^{\star *}$ & 0.621 & 1.77 \\
\hline Agro chemicals & 0.192 & 1.24 & 0.771 & 1.06 & 0.025 & 1.30 & 0.034 & 1.26 \\
\hline Fertilizer & 0.395 & $1.77^{\star *}$ & 2.911 & $4.07^{\star \star \star}$ & 0.044 & 2.04 & 1.681 & $2.00^{* *}$ \\
\hline Dummy & & & & & & & 1.937 & $2.96^{* *}$ \\
\hline$R^{2}$ & 0.7051 & & 0.6431 & & 0.7290 & & 0.6911 & \\
\hline Adj $R^{2}$ & 0.6512 & & 0.0687 & & 0.6755 & & 0.6128 & \\
\hline $\mathrm{F}$ ratio & $3.05^{\star \star \star}$ & & $2.03^{\star \star \star}$ & & $3.96^{* * *}$ & & $2.56^{\star \star *}$ & \\
\hline
\end{tabular}

Chow test for structural break at observations 30 were as follows:

Test statistics $F(7,46)=2.36892$

With $p$-value $p(F(7,46)>2.36892=0.0373194$

\subsection{Hypothesis Testing}

From the study, t-calculated (2.36892) was greater than t-tabulated (0.0373194) at 5 percent significance level. Therefore, $\mathrm{Ho}_{1}$ which states that there is no significant relationship between smallholder farmers output and migrant remittances is rejected. This implies that migrant remittance influenced farmers output significantly. Also $\mathrm{Ho}_{2}$ states that there is no significant difference between (farm size, labour, fertilizer, age, education farming experience) and output of remittance receiving and non-remittance receiving households are rejected. 


\section{Conclusion}

The study measured the impact of migrant remittances on agricultural production. Multiple regression based on Cobb Douglas was used to analyse the data. Results revealed that remittances contributed significantly to increased agricultural output in remittance receiving households. Findings also showed that education, experience, farm size, household type and labour were the most important drivers of smallholder farmers agricultural output. Education is a vital asset for increasing agricultural output in both remittance and non remittance receiving households. It is therefore essential to improve the human capital development of farmers. Through education and training, farmers are well informed about climate change events and will be able to make rational decisions regarding the allocation of remittances and other resources towards mitigating the negative effect of climate change. Apart from using migrant remittances for construction and education, this study is suggestive that families could also gain if remittances are ploughed into meaningful agricultural production. Remittances have been shown to impact agricultural output positively; therefore, increasing the flow of remittance into the country would help smallholder farmers to expand agricultural production. Policy measures should also be followed strictly to reduce the charges and constraints associated with receiving remittances from relatives abroad.

\section{References}

Asogwa, U. G. (2013). Migration, Remittances and Livelihood systems of farm households in Enugu State, Nigeria. 3(7):184-191. Babatunde, R. O. and Martinett, E. C. (2010). Impact of remittances on food security and nutrition in rural Nigeria. Department of Public Economics, University of Parvia, Italy.

Chukwuone, N., Amaechina, E., lyoko-Enebelizor S. E. and Okpukpara, B. (2007). Analysis of Impact of Remittance on poverty and inequality in Nigeria. Research Paper presented at 6 Poverty Economic Policy (PEP), Research Network General Meeting, PMMA Network.

Davis J, Lopez-Carr D. (2014). Migration, remittances and smallholder decision-making: implications for land use and livelihood change in Central America. Land use policy. 36:319-29.

Etim, N. A. and Edet, G. E. (2014). Do migrant remittances reduce rural poverty? European International Journal of Science and Technology 2(9): 133-140.

Etim, N. A. and Etim, N. N. (2020). Rural Farmers' adaptation decision to climate change in Niger Delta Region, Nigeria. In Leal Filho W. (ed.) Handbook of Climate Change Resilience. Springer, Cham.

Gupta, S., Pattillo, C. A. and Wagh, S. (2009). Effect of Remittances on Poverty and Financial Development World Development 37(1): 1-24.

Huy, H. T. and Nonneman, W. (2015). Economic Effects of labour migration on agricultural production of farm households in Mekong River Delta region of Vietnam. Asian and Pacific Migration Journal 25(1): 3-21.

Iheke, O. K. (2014). Impact of Migrant Remittances on the Output of Arable Crop of Farm Households in South Eastern Nigeria. American Journal of Experimental Agriculture 4(10): 1209-1218.

Iheke, O. R. and Aniocha, C. M. (2017). Migrant Remittances, savings and investments among rural farm households in Abia State, Nigeria Journal of Nutritional Ecology and Food Research 4(1): 28-33.

Koutsoyiannis, A. (2001). The Theory of Econometrics ( $2^{\text {nd }}$ Ed), New York: Palmgrave Publishers Ltd. 164-166.

Muller, C., Cramera, W., Hare, W. L., Lotzecampena, H. (2011). Climate change risk for African agriculture, Proc. Natl. Acad. Sci. USA 108:4313-4315.

Musah-Surugu, I. J., Ahenkan, A., Bawole, J.N and Darkwah, S.A (2018). Migrants' remittances. A Complimentary source of financing adaptation to climate change at the local level in Ghana. International Journal of Climate Change Strategies and Management 10(1): 178-196

Ndamani, F. and Watanabe, T. (2017). Determinants of Farmers' Climate Risk Perceptions in Agriculture: A Rural Ghana Perspective Water. 9(210): 1-14.

NPC (National Population Commission) (2006). Population Census of the Federal Republic of Nigeria. Analytical Report at the National Population Commission, Abuja.

Nwaru, J. C., Iheke, O. R. and Onyenweaku, C. E. (2011). Impact of migrant remittances on the Welfare of Arable Crop Farm Household in South Eastern Nigeria. Research in Human Ecology 18(2): 159-166.

Olomola, A. S. (1998). Choice and Productivity Effects of Animal Traction Technology in the semi-Arid zone of Northern Nigeria. Issues in African Development Monograph Series 12:9.

Onyenweaku, C. E. (1997). Impact of Technological change on Output, Income, Employment and Factor shares in rice production in South Eastern Nigeria. Issues in African Development Monograph Series 5:7-8.

Orozco, M. \& Jewers, M (2019). The impact of migrants remittances and investment on rural youth. Papers of the 2019 Rural Development Report. 56 IFAD Research series.

Oseni, G. and Winter, P. (2009). Rural nonfarm activities and agricultural crop production in Nigeria. Agricultural Economics 40(2): 189-201.

Osondu, C. K., Ibezim, G. M. C., Obike, K. and ljiomah, J. C. (2014). Rural-urban migration, remittance economy and agricultural investment among small scale farmers Umuahia south local government of Abia State, Nigeria. Sky Journal of Agricultural Research 3(4): 62-66. 
Redehegn, M. A., Sun, D., Eshete, A.M \& Gichuki,C.N (2019). Development impacts of migration and remittances on migrantsending communities: Evidence from Ethiopia 14(2): e0210034. 